Original Research Paper

\title{
Roles of animal trophies in museums on conservation practices: case study of Palace museums of the west region of Cameroon
}

\author{
Mfonden P.M.M' ${ }^{1}$, Meutchieye $\mathbf{F}^{2}$ \\ ${ }^{1}$ Department of Forestry, Faculty of Agronomy and Agricultural Sciences, University of Dschang, \\ Cameroon. \\ ${ }^{2}$ Department of Animal Science, Faculty of Agronomy and Agricultural Sciences, University of Dschang,
}

*Corresponding Author: Meutchieye F., University of Dschang, Cameroon. Email: fmeutchieye@gmail.com

Article history; Received: October $1^{\text {st }} 2020$; Revised: November $10^{\text {th }} 2020$; Accepted: December $20^{\text {th }} 2020$

\begin{abstract}
Palace museums harbour important animal remains (trophies), this is the case too with palace muse ums of the West region of Cameroon. Here we present a preliminary study into the animal-based collections of palace museums from a genetic conservation perspective. We surveyed 11 chiefdom palace museums in the West Region of Cameroon. We collected samples of these trophies. We extracted and purified DNA from these trophies using the DNeasy® Blood and Tissue Kit. Quantification and quality control were done using the agarose gel electrophoresis and spectrophotometric methods. From agarose gel electrophoresis, $64 \%$ of specimens have DNA that could be of good quality, $12 \%$ of specimens have contaminated DNA, while $12 \%$ of specimens have degraded DNA. Spectrophotometric determination reveals that $28 \%$ of the specimens has quantifiable DNA against $72 \%$ that was of poor DNA quantity. Specimens with good quality DNA could be used for further studies (for instance, DNA sequencing for wildlife traceability). In order to perpetuate the conservation role played by the tradition through museums, the administration has to regulate the acquisition and use of trophies in traditional and cultural events in the forest law actually under revision. Museums have to ensure compliance with the criteria of acquisition and management of wildlife trophies
\end{abstract}

Key words: Conservation, gDNA, Museum, Wildlife, West Cameroon.

\section{Introduction}

The wildlife has important livelihood aspects and serves multiple roles. Wildlife products are often major items of consumption or display and have high medicinal and spiritual values in many human cultures (Lohani, 2011). Unsustainable harvest of forest resources presents a major threat to animal welfare, particularly in Africa where these animals fulfil traditional needs. Archaeological researchers have determined that humans have consumed a wide variety of fish, molluscs, birds, mammals, reptiles and amphibians for at least 1,500 years (Pohl, 1976; Pohl, 1981; McKillop, 1985; Hamblin, 1985; Masson, 1999; Foster and James, 2002; Emery, 2007; Kyselý, 2008; Masson and Peraza Lope, 2008) and perhaps as many as 4,000 years (Jorgenson, 1998).

Hunting is one of oldest known human activities, and animals have been hunted for utilitarian reasons as well as for defence against large predators (Alves, 2012). Faunal derived products are used in many ways, especially as food, but also as clothing and tools, and for medicinal and magic-religious purposes (Alvard et al., 1997; Prins et al., 2000; Alves and Pereira Filho, 2007; Alves et al., 2009; Inskip and Zimmermann, 2009). 
This enduring relationship of dependence has also contributed to the formation of affective links with certain animals, and many species were kept (and continue to be kept) as pets, especially birds and mammals and, more recently, reptiles and amphibians (Hoover, 1998; Franke and Telecky, 2001; Alves et al., 2010a; Alves et al., 2012a). These relationships with animals go beyond simple utilitarian considerations, for there have been strong supernatural relationships between the worlds of humans and animals since remote times (Alves, 2012). All human cultures have mythologies, and all of them show close integration and connections with animals, and totemic, ancestral or mythological (imaginary) animals or animal gods have been present throughout human history (Allaby, 2010; Alves et al., 2012b).

Interest in collecting, especially in the natural sciences, has recently arisen in the history and philosophy of science and other fields (Ikin, 2011). The collecting of animals for preservation is a familiar description of one of the functions of a modern museum. Museum collecting of animals is a multi-modal practice and is currently conducted with a number of objects in mind: taxonomic collecting; research or problem-based collecting; collecting for exhibition and public programs (Kohler, 2007).

Conservation of biodiversity in the current era is a priority in the scientific agendas of museums of natural heritage (Kohler, 2006). Genetic and museum data on species used for traditional purposes in Cameroon are almost non-existent. This lack of reliable and up-to-date data is strongly felt by forestry administrations or even by the CITES wild meat and trophy Working Group initiated in 2000 in Nairobi, Kenya (CITES Afrique, 2016). In addition, little is known of the role-play by museums in wildlife genetic conservation within the Congo Basin. This gap needs to be filled by conducting studies that can provide baseline data for the traceability of species used for cultural purposes.

\section{Methodology}

\section{Survey area}

Located at latitude $5^{\circ} 30^{\prime} \mathrm{N}$ and longitude $10^{\circ} 30^{\prime} \mathrm{E}$, the West Region is $14,000 \mathrm{~km}^{2}$ of territory located in the central-western portion of the Republic of Cameroon. It borders the Northwest Region to the northwest, the Adamawa Region to the northeast, the Centre Region to the southeast, the Littoral Region to the southwest, and the Southwest Region to the west. The West Region is the smallest of Cameroon's ten regions in area, yet it has one of the highest population density in Cameroon (MINADER RD, 2014). Figure 1 shows the locations of museums in which the study is conducted.

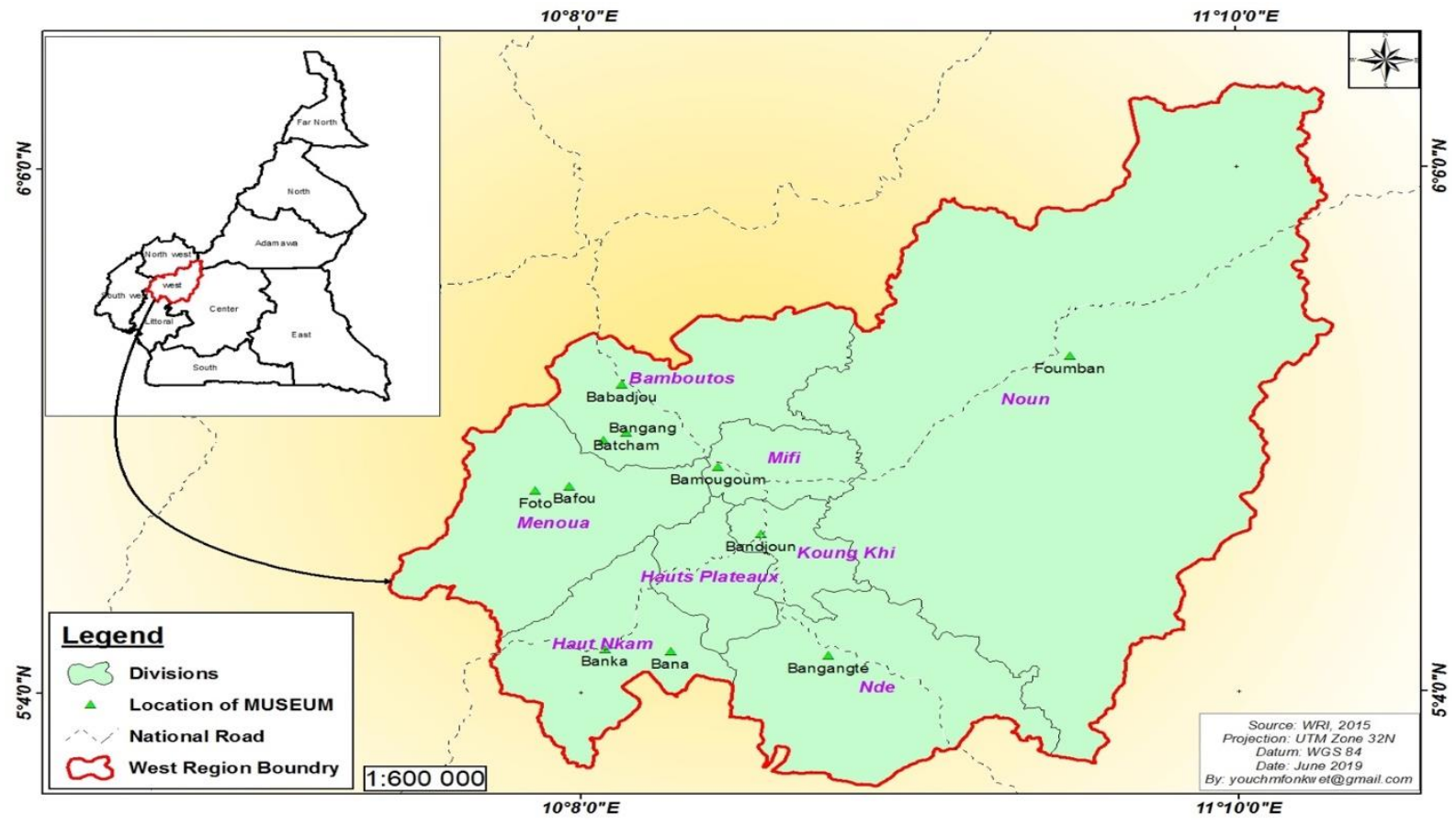

Figure 1: Localization of the area of study 
The climate is equatorial of Cameroon type with sub varieties in the North-western part and equatorial of Guinea type in the South-eastern part. Rainfall, moderated by the mountains, averages 1,000-2,000 $\mathrm{mm}$ per year throughout, though it is highest at the area of the Bamendjing reservoir, temperature vary around $22^{\circ} \mathrm{C}$ (MINADER RD, 2014). There are relics of natural forests along streams and "sacred forests" populated mainly by Ficus spp., Polyscia fulva; Dracaena arborea, Albizia spp. (DR MINFOF Ouest, 2009).This Region is dominate by the Bamileke and the Bamoun. (Despois, 1945). They organise themselves in sub-groups, each under the rule of a different chief.

\section{Data Collection}

The West region counts eleven (11) first-degree chieftaincies, a hundred and eight (108) second degree and over five hundred (500) third degree chieftaincies (MINATD, 2014). The first-degree chieftaincies are: The Bamoun sultanate in the Noun Division; Babadjou, Bangang and Batcham all of the Division of Bamboutos; Foto and Bafou of the Menoua Division; Banka and Bana of the Higher Nkam Division; Bamougoum of the Division of Mifi; Bangangte of the Division of Nde; and Bandjoun of the Division of Koung-khi. We did a reasoned sampling, targeting these first-degree chieftaincies.

We addressed semi-structured questionnaires to museum staffs concerning each of the trophy present in these units. Field guides were used to confirm the name of the species given by museum staffs. Samples of these trophies were collected to test for the DNA quality and quantity.

\section{Laboratory analysis}

The purification of total DNA from compact animal tissues using the DNeasy® Blood was as follows:

1. Completely remove bone marrow and soft tissues using razor blade and/or sandpaper

2. Crush the bone into small fragments. Grind to a fine powder using a metal blender half-filled with liquid nitrogen.

3. Place up to $100 \mathrm{mg}$ of the powdered bone into a $1.5 \mathrm{ml}$ micro centrifuge tube. Proceed immediately with step 7.

4. Add $360 \mu$ I BUFFER ATL and $40 \mu 1$ proteinase $\mathrm{K}$. Mix by vortexing, and incubate at $56^{\circ} \mathrm{C}$ until the pellet is completely lysed. Vortex occasionally during incubation to disperse the sample, or place in a shaking water bath or on a rocking platform

5. VORTEX for $15 \mathrm{~s}$ add $400 \mu \mathrm{l}$ buffer AL to the sample and mixed thoroughly by vortexing. Then add $400 \mu$ l ethanol (96 to 100\%) and mixed again thoroughly by vortexing. It is essential that the sample, Buffer AL and ethanol can be premixed and added together in one-step to save time when processing multiple samples.

6. Pipet up to $650 \mu 1$ of the mixture from step 5 (including the precipitate) into the DNeasy Mini spin column placed in a $2 \mathrm{ml}$ collection tube (provided). Centrifuge at $\geq 6000^{*} \mathrm{~g}$ (8000 rpm) for $1 \mathrm{~min}$. Discard flow-through and reuse the collection tube.

7. Repeat step 6 until all of the sample has been loaded.

8. Place the DNeasy Mini spin column in a new $2 \mathrm{ml}$ collection tube (provided), add 500 $\mu$ l Buffer AW1, and centrifuge $1 \mathrm{~min}$ at $\geq 6000 * \mathrm{~g}(8000 \mathrm{rpm})$. Discard flow-through and collection tube.

9. Place the DNeasy Mini spin column in a new $2 \mathrm{ml}$ collection tube (provided), add 500 $\mu 1$ Buffer AW2, and centrifuge for $3 \mathrm{~min}$ at $20000 * \mathrm{~g}(14000 \mathrm{rpm})$ to dry the DNeasy membrane. Discard flow-through and collection tube.

10. Place the DNeasy Mini spin column in a clean $1.5 \mathrm{ml}$ or $2 \mathrm{ml}$ micro centrifuge tube (not provided), and pipet $200 \mu \mathrm{l}$ Buffer AE or water directly onto the DNeasy membrane.

Incubate at room temperature for $1 \mathrm{~min}$, and then centrifuge for $1 \mathrm{~min}$ at $\geq 6000 * \mathrm{~g}(8000 \mathrm{rpm})$ to elute.

Elution with $100 \mu \mathrm{l}$ (instead of $200 \mu \mathrm{l}$ ) increase the final DNA concentration in the eluate, but also decreases the overall DNA yield (see DNeasy Blood \&Tissues Handbook). 
11. Recommended: for maximum DNA yield, repeat elution once s described in step 10. This step leads to increase over DNA yield.

A new micro centrifuge tube can be used for the second elution step to prevent dilution of first eluate. Alternatively, to combine the eluates, the micro centrifuge tube from step 10 can be reused for the second elution step.

Note: don't elute more than $200 \mu \mathrm{l}$ into a $1.5 \mathrm{ml}$ micro centrifuge tube because DNeasy Mini spin column in will come into contact with the eluate.

\section{Agarose gel electrophoresis}

1. Attach tape to the ends of the gel tray. Position the well-forming comb and ensure that the gel tray is horizontal.

2. Prepare a $0.8 \%$ agarose gel: dissolve $0.24 \mathrm{~g}$ agarose in $30 \mathrm{ml} 0.5 \mathrm{x}$ TBE or Ix Methods 19 TAE. Heat the mixture in a microwave oven until completely dissolved, taking care to avoid boiling. Cool to $60^{\circ} \mathrm{C}$ then add 1.5 III of ethidium bromide stock solution and swirl gently to mix well.

3. Pour agarose onto the gel tray and allow it to set for at least $30 \mathrm{~min}$.

4. Remove the comb and tape. Place the gel into the electrophoresis tank and pour Ix TAE until the gel is completely covered. The electrophoresis buffer used must be the same as the gel buffer.

5. Mix 4 III distilled deionized water, 1 III loading dye and 1 III DNA and load onto the gel.

6. Load 2111 of HindIII digested X. DNA (2 Ilg) into one of the wells.

7. Run the gel at $60-70 \mathrm{~V}$ until the dye is $3-4 \mathrm{~cm}$ from the wells.

8. Illuminate the gel with UV light.

9. Photograph the gel under the UV.

\section{Spectrophotometric determination of DNA concentration}

Dilute $1.5 \mu 1$ of DNA to $1500 \mu 1$ with distilled deionized water and read the A230/A260 and A280. The A260/ A280 ratio provides an estimate of the purity of the nucleic acid. In a pure DNA sample this ratio should be around 1.8. Lower values indicate protein or phenol contamination. A230 should be less than A260 and may be the same as the A280. High A230 readings indicate that residual phenol remains in the preparation.

\section{Results}

\section{Species exploited in museums}

We encountered 32 species used in museums as trophies. Table 1 presents these encountered species.

According to table 1, 32 species are found in surveyed museums. The African Buffalo (Syncerus caffer) represent the highest encounter (22.9\%). Duikers (Cephalophus spp.) follow with a proportion of $10.8 \%$, then leopards (Panthera pardus) with a proportion of $7.2 \%$. The species bushbuck, cheetah, cow, crocodile, genet, goat, green mamba, guinea fowl, horse, porcupine-fish, python, sable antelope, turtle, sheep, sparrow hawk and African bush viper are the least represented with a percentage of 1.2. 
Table 1: Species found in museums of Cameroon West region

\begin{tabular}{|c|c|c|c|c|}
\hline No. & Species & & Frequency & Percent $(\%)$ \\
\hline & Common Name & Scientific Name & & \\
\hline 1 & Brush-tailed porcupine & Atherurus africanus & 3 & 3.6 \\
\hline 2 & Bushbuck & Tragelaphus sylvaticus & 1 & 1.2 \\
\hline 3 & African Buffalo & Syncerus caffer & 19 & 22.9 \\
\hline 4 & Cheetah & Acinonyx jubatus & 1 & 1.2 \\
\hline 5 & Chimpanzee & Pan paniscus & 2 & 2.4 \\
\hline 6 & Cobra & Naja spp. & 2 & 2.4 \\
\hline 7 & Cow & Bos Taurus & 1 & 1.2 \\
\hline 8 & Cowry & Cypraea spp. & 2 & 2.4 \\
\hline 9 & Crocodile & Crocodylus nitoticus & 1 & 1.2 \\
\hline 10 & Duiker & Cephalophus spp. & 9 & 10.8 \\
\hline 11 & Elephant & Loxodonta africana Africana & 3 & 3.6 \\
\hline 12 & Genet & Genetta genetta & 1 & 1.2 \\
\hline 13 & Goat & Capra spp. & 1 & 1.2 \\
\hline 14 & Green mamba & Dendroaspis jamesoni & 1 & 1.2 \\
\hline 15 & Guinea fowl & Numida meleagris & 1 & 1.2 \\
\hline 16 & Hartebeest & Alcelaphus buselaphus & 2 & 2.4 \\
\hline 17 & Hippopotamus & Hippopotamus amphibius & 3 & 3.6 \\
\hline 18 & Horse & Equus spp. & 1 & 1.2 \\
\hline 19 & Leopard & Panthera pardus & 6 & 7.2 \\
\hline 20 & Lion & Panthera leo & 3 & 3.6 \\
\hline 21 & Mussels & Mytilus spp. & 2 & 2.4 \\
\hline 22 & Porcupinefish & Diodon nicthemerus & 1 & 1.2 \\
\hline 23 & Puku & Kobus vardoni & 2 & 2.4 \\
\hline 24 & Python & Python sabae & 1 & 1.2 \\
\hline 25 & Red Viper & Atheris squamigera & 2 & 2.4 \\
\hline 26 & Sable antelope & Hippotragus niger & 1 & 1.2 \\
\hline 27 & Sassaby & Damaliscus lunatus & 2 & 2.4 \\
\hline 28 & Turtle & Chelonia spp. & 1 & 1.2 \\
\hline 29 & Sheep & Ovis aries & 2 & 2.4 \\
\hline 30 & Sitatunga & Tragelaphus spekei & 4 & 4.8 \\
\hline 31 & Sparrow hawk & Accipiter spp. & 1 & 1.2 \\
\hline 32 & African bush viper & Atheris spp. & 1 & 1.2 \\
\hline
\end{tabular}

\section{Parts of the animal used}

Of the 32 species found in museums, none of them was whole. The figure below shows the parts of the animals used and their respective frequencies.

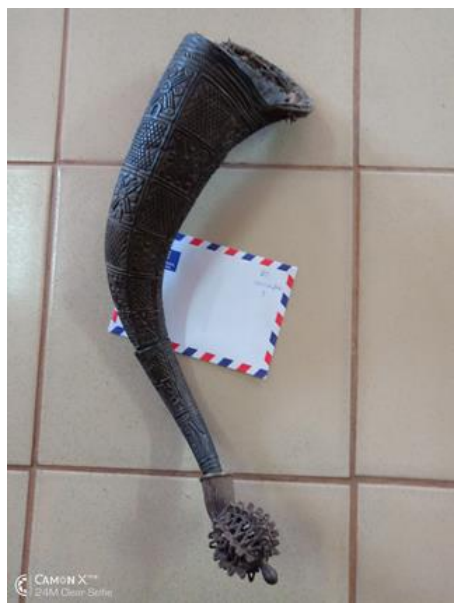

2a: Buffalo's horn

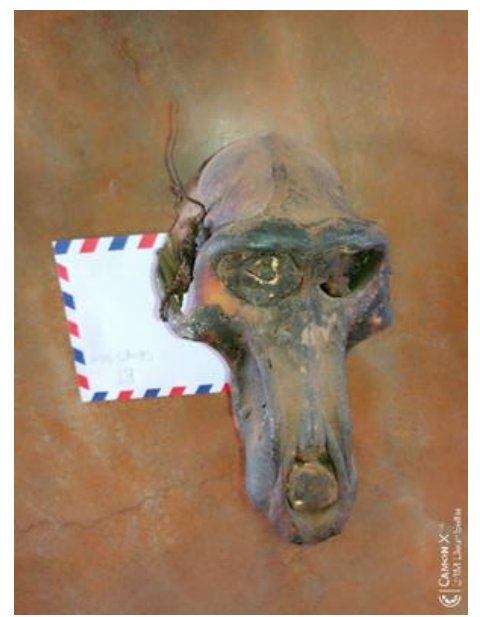

2b: Chimps'skull

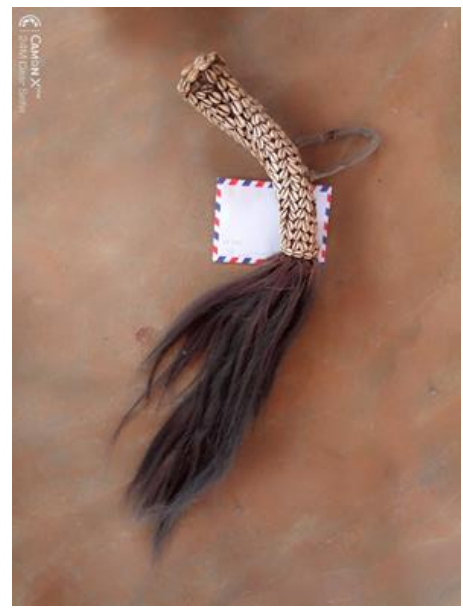

2c: Buffalo's tail 


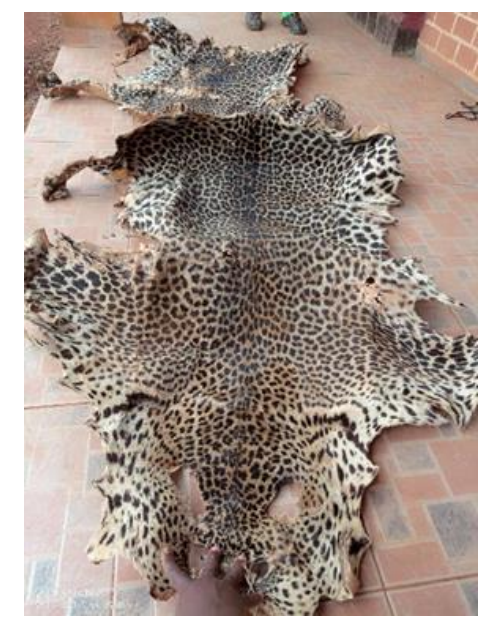

2d: leopard's skin

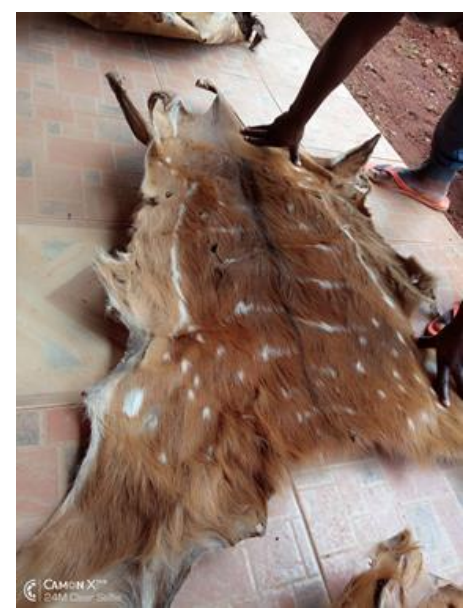

2e: Sitatunga's skin

Figure 2: Some animals displayed in the Museums

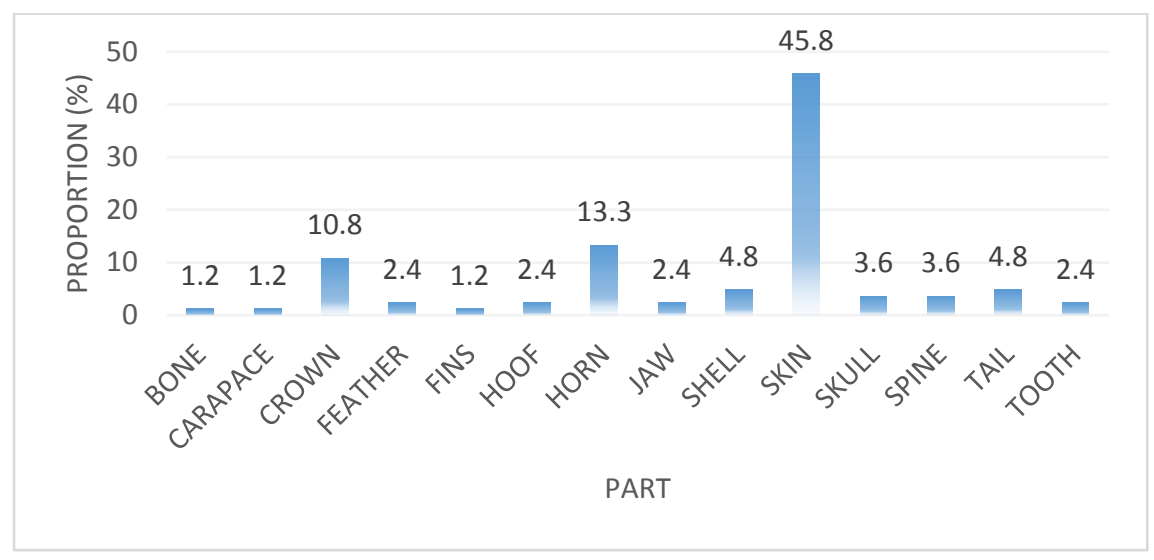

Figure 3: Animals' parts founds in the Museums

According to figure 7 , the skin records $45.8 \%$ of all the trophies found in museums, this represents the most used part of animal. The horn (13.3\%), then the crown (10.8\%) follow it. This is normal due to fact that the skin is that part of an animal that represents the animal the most. The horn also characterizes each animal. The bone, the carapace and fins are the least used part (with $1.2 \%$ each).

\section{DNA quality and quantity of trophies found in museums}

Quality control and quantification of DNA is a very important step in many procedures where it is necessary to know the purity and amount of DNA that is present when carrying out restriction digests or performing different techniques such as PCR and RAPDs.

\section{Agarose gel electrophoresis}

Agarose gel electrophoresis is a method for the separation and analysis of macromolecules (DNA, RNA and proteins) and their fragments, based on their size and charge, using agarose as a gel medium. The visualization of agarose gel amplification results confirms the reliability of DNA extracted from fresh, smeared, cooked and dried tissues by extraction kits. Figure 4 show the result obtained from the agarose gel electrophoresis of 25 specimens. 


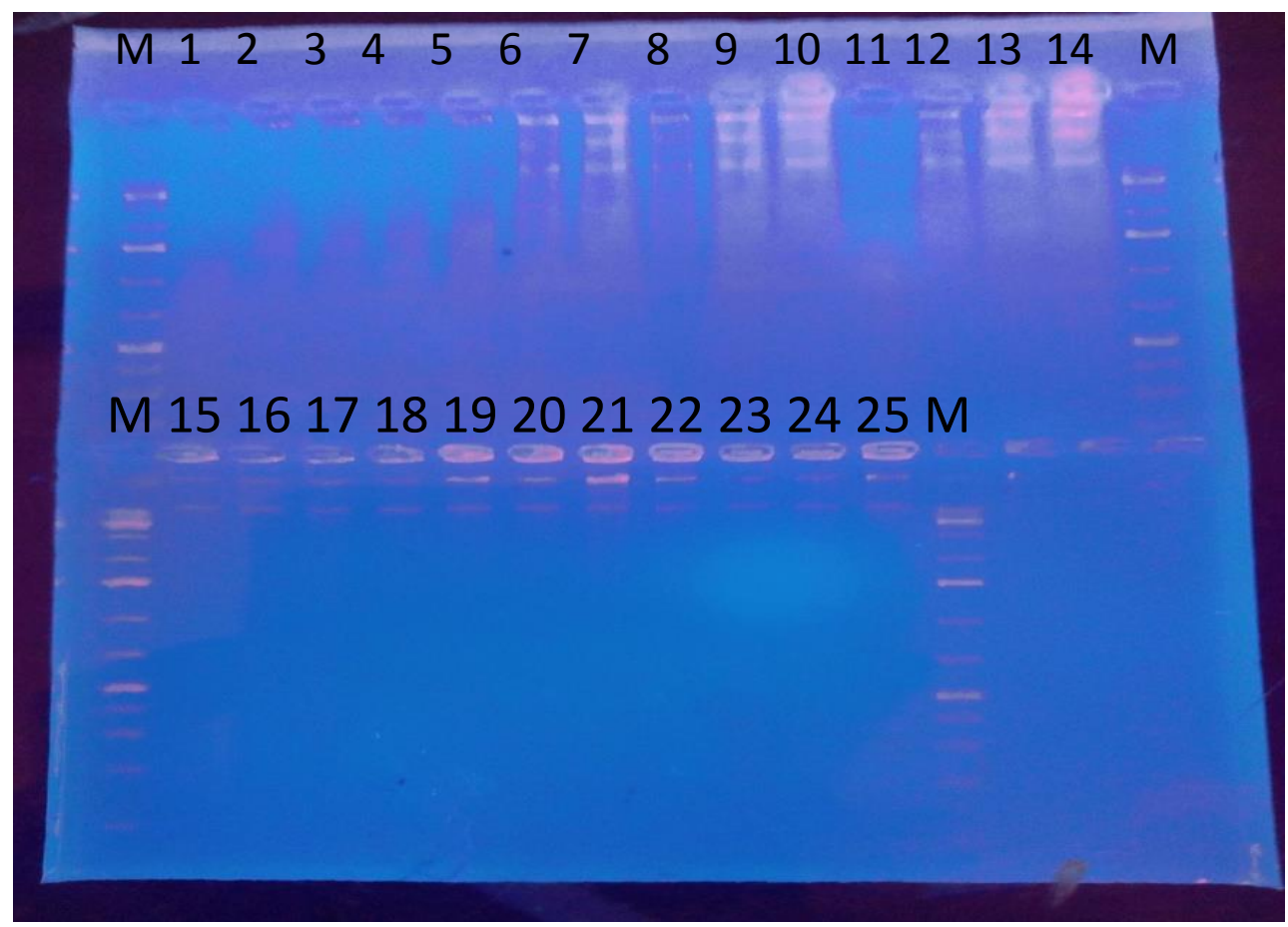

Key :
1: Buffalo's skin
2: Buffalo's crown
3: Buffalo's horn
4: Buffalo's tail
5: Cheetah's skin
6: Chimpanzee's tooth
7: Chimpanzee's skull

\author{
8: Cobra's skin \\ 9: Crocodile's skin \\ 10: Elephant's bone \\ 11: Elephant's jaw \\ 12: Elephant's tooth (ivory) \\ 13: Hippopotamus' jaw
}

\author{
14: Hippopotamus' tail \\ 15: Hippopotamus' skull \\ 16: Leopard's skin \\ 17: Lion's skin \\ 18: Lion's skull \\ 19: Python's skin
}

20: Red viper's skin

21: Viper's skin

22: Turtle's carapace

23: Sitatunga's crown

24: Sitatunga's skin

25: Sitatunga's horn

M: Maker

Figure 4: Agarose gel electrophoresis

According to Rosario et al. (1998), the Agarose gel electrophoresis test of figure 4 could be interpreted as follows: specimens $1,2,3,4,5,11,15,16,17,18,19,20,22,23,24,25$ could be of good DNA quality, specimens 7, 9, 21 could have DNA contaminated with salts, specimens $6,8,12$ could have DNA mixed with RNA and specimens 10,13, 14 have degraded DNA. Specimens with degraded DNA (elephant's bone, hippopotamus' jaw and tail) are actually specimens that date as early as from the nineteen century and could have weather with time. From this interpretation, $64 \%$ of the specimens are of good quality, $24 \%$ of these specimens has contaminated DNA (12\% contaminated with salts such as phenol and $12 \%$ are mixed with RNA), and $12 \%$ of these specimens have degraded DNA.

This result shows that $64 \%$ of these specimens can be used for further studies (DNA sequencing) this could be of great importance in the traceability of these species.

\section{Spectrophotometric determination}

The nucleic acids and proteins have a maximum abundance of 260 and $280 \mathrm{~nm}$ respectively. Historically, the abundance ratio of these wavelengths has been used to measure the purity of extractions of nucleic acids and proteins (Thermo Fisher Scientific, 1997). The table below gives the quantities and the ratios of nucleic acid extracted from the different animal tissues. Ratios substantially equal to 1.8 are generally acceptable for pure genomic DNA (Thermo Fisher Scientific, 1997). Thus, these ratios closely related to the different concentrations make it possible to carry out the dilutions of the DNAs. 
Table 2: Quantities and the ratios of nucleic acid extracted from animal tissues

\begin{tabular}{|c|c|c|c|c|c|c|}
\hline $\begin{array}{l}\mathbf{N} \\
\mathbf{0}\end{array}$ & species & $\begin{array}{l}\text { specimen } \\
\text { No }\end{array}$ & $\begin{array}{l}\text { specime } \\
\text { n }\end{array}$ & $\begin{array}{l}\text { conc. } \\
\mathrm{Ng} / \mu \mathrm{l} \\
\end{array}$ & $\begin{array}{l}260 / 280 \\
\text { ratio }\end{array}$ & $\begin{array}{l}260 / 230 \\
\text { ratio } \\
\end{array}$ \\
\hline \multirow[t]{4}{*}{1} & \multirow[t]{4}{*}{ Buffalo (Syncerus caffer) } & 1 & skin & 32.2 & 1.684 & 0.419 \\
\hline & & 2 & crown & 500.6 & 1.030 & 1.127 \\
\hline & & 3 & horn & 0 & 0 & 0 \\
\hline & & 4 & tail & 0 & 0 & 0 \\
\hline 2 & Cheetah (Acinonyx jubatus) & 5 & skin & 0 & 0 & 0 \\
\hline \multirow[t]{2}{*}{3} & \multirow[t]{2}{*}{ Chimpanzee (Pan paniscus) } & 6 & tooth & 0 & 0 & 0 \\
\hline & & 7 & skull & 12.5 & 3.060 & 0.309 \\
\hline 4 & Cobra (Naja spp.) & 8 & skin & 99.1 & 0.968 & 0.288 \\
\hline 5 & Crocodile (Crocodylus nitoticus) & 9 & skin & 0 & 0 & 0 \\
\hline \multirow[t]{3}{*}{6} & \multirow[t]{3}{*}{ Elephant (Loxodonta africana Africana) } & 10 & bone & 0 & 0 & 0 \\
\hline & & 11 & jaw & 0 & 0 & 0 \\
\hline & & 12 & ivory & 0 & 0 & 0 \\
\hline \multirow[t]{3}{*}{7} & \multirow{3}{*}{$\begin{array}{l}\text { Hippopotamus } \\
\text { amphibius) }\end{array}$} & 13 & jaw & 0 & 0 & 0 \\
\hline & & 14 & tail & 0 & 0 & 0 \\
\hline & & 15 & skull & 0 & 0 & 0 \\
\hline 8 & Leopard (Panthera pardus) & 16 & skin & 0 & 0 & 0 \\
\hline \multirow[t]{2}{*}{9} & \multirow[t]{2}{*}{ Lion (Panthera leo) } & 17 & skin & 0 & 0 & 0 \\
\hline & & 18 & skull & 0 & 0 & 0 \\
\hline 10 & Python (Python sabae) & 19 & skin & 26.8 & 0.729 & .300 \\
\hline 11 & Red viper (Atheris squamigera) & 20 & skin & 7.6 & 0.562 & 0.078 \\
\hline 12 & Viper (Atheris spp.) & 21 & skin & 20.6 & 1.074 & 0.232 \\
\hline 13 & Sea turtle (Chelonia spp.) & 22 & carapace & 0 & 0 & 0 \\
\hline \multirow[t]{3}{*}{14} & \multirow[t]{3}{*}{ Sitatunga (Tragelaphus spekei) } & 23 & crown & 0 & 0 & 0 \\
\hline & & 24 & skin & 0 & 0 & 0 \\
\hline & & 25 & horn & 0 & 0 & 0 \\
\hline
\end{tabular}

\section{Conclusion}

At the end of this study that focused on the implication of the presence of animal trophies to conservation in royal museums of the West region of Cameroon, we found out that these trophies play a vital role in conservation. It appears that thirty-three (32) species were exploited in museums, with the African Buffalo (Syncerus caffer) being most frequent. None of this species was whole and the skin of this species were the most frequent. The class Mammalia represents $62.5 \%$ of all the species exploited in museums. From agarose gel electrophoresis, $64 \%$ of specimens could be of good DNA quality, $24 \%$ are contaminated and $12 \%$ of these are degraded DNA. Spectrophotometric determination reveals that $28 \%$ of the specimens has quantifiable DNA against $72 \%$ that was of poor DNA quantity, but for specimen 1 whose 260/280 ratio is 1.7 (close to 1.8). As a whole, from this study, it is clear that the main role of the presence of animal trophies in museums of the west Region of Cameroon is not for genetic conservation, but strategies can be put in place in order to meetup with this form of conservation.

\section{Acknowledgements}

Authors are thankful to the National veterinary laboratory, for providing laboratory facilities. Special thanks to all the traditional rulers in the West Region of Cameroon and to museum attendants.

\section{References}

Allaby M 2010. Animals: from mythology to zoology. Facts On File, Inc., New York.

Alvard MS. Robinson JG. Redford KH. Kaplan H 1997. The Sustainability of Subsistence Hunting in the Neotropics. Conservation Biology 11:977-982.

Alves RRN 2012. Relationships between fauna and people and the role of ethnozoology in animal conservation. Ethnobiology and Conservation. 1:1-69.

Alves RRN. Mendonça LET. Confessor MVA. Vieira WLS. Lopez LCS 2009. Hunting strategies used in the semi-arid region of northeastern Brazil. Journal of Ethnobiology and Ethnomedicine $5: 150$. 
Alves RRN. Nogueira E. Araujo H. Brooks S 2010a. Bird-keeping in the Caatinga, NE Brazil. Human Ecology 38:147-156.

Alves RRN. Pereira Filho GA 2007. Commercialization and use of snakes in North and Northeastern Brazil: implications for conservation and management. Biodiversity and Conservation 16:969985.

Alves RRN. Rosa IL. Léo Neto NA. Voeks R 2012b. Animals for the Gods: Magical and Religious Faunal Use and Trade in Brazil. Human Ecology 40:751-780.

Alves RRN. Vieira KS. Santana GG. Vieira WLS. Almeida WO. Souto WMS. Montenegro PFGP. Pezzuti JCB 2012a. A review on human attitudes towards reptiles in Brazil. Environmental Monitoring and Assessment 184:6877-6901.

Borrow N. \& Demey R 2015. Birds of western Africa. Second Edition. ISBN: 9780691159201.

CITES Afrique 2016. Lettre d'Information sur la Convention sur le Commerce International des Espèces de Faune et de Flore Sauvages Menacées d'Extinction (CITES) spécialisée sur l'Afrique 21. $4 p$.

Délégation Régionale MINFOF Ouest 2009. Rapport d'activité annuel.

Despois J 1945. Des montagnards en pays tropical. Bamiléké et Bamoun (Cameroun Français. Revue de Géographie Aipinel 33-4/ 595-634.

Emery KF 2007. Assessing the impact of ancient Maya animal use. Journal for Nature Conservation 15:184-195.

Foster MS. James SR 2002. Dogs, Deer, or Guanacos: Zoomorphic Figurines from Pueblo Grande, Central Arizona. Journal of Field Archaeology 29:165-176.

Franke J. Telecky TM 2001. Reptiles as pets: an examination of the trade in live reptiles in the United States. Humane Society of the United States, Washington (DC).

Hamblin NL 1985. The role of marine resources in the Maya economy: a case study from Cozumel, Mexico. Prehistoric lowland Maya environment and subsistence economy. Cambridge: Harvard University, The Peabody museum of American archaeology and ethnology, pp. 159-173.

Hoover C 1998. The US role in the international live reptile trade: Amazon tree boas to Zululand dwarf chameleons. TRAFFIC North America.

Ikin T 2011. A Conservation Ethic and the Collecting of Animals by Institutions of Natural Heritage in the Twenty-First Century: Case Study of the Australian Museum. Department of Museum Studies, School of Letters, Arts and Media, Faculty of Arts, University of Sydney, Sydney, NSW 2006, Australia. ISSN 2076-2615.

Inskip C. Zimmermann A 2009. Human-felid conflict: a review of patterns and priorities worldwide. Oryx 43:18-34.

Jorgenson JP 1998. The impact of hunting on wildlife in the Maya Forest of Mexico. Timber, tourists and temples: Conservation and development in the Maya forests of Belize, Guatemala and Mexico. Island Press, Washington D.C., pp. 179-194.

Kingdon J 2004. African mammals. The kingdom pocket guide, 272p.

Kohler RE 2006. All Creatures: Naturalists, Collectors and Biodiversity, Princeton University Press: Princeton, NJ, USA, 1850-1950.

Kohler RE 2007. Collecting Sciences and Collecting Practice. Finders, Keepers.Hist. Sci., 45, 428-454.

Kyselý R 2008. Frogs as a part of the Eneolithic diet. Archaeozoological records from the Czech Republic (Kutná Hora-Denemark site, Rivnác Culture). Journal of Archaeological Science 35:143-157.

Lohani U 2011. Traditional Uses of Animals among Jirels of Central Nepal. Ethno Med, 5(2): 115-124.

Masson MA 1999. Animal Resource Manipulation in Ritual and Domestic Contexts at Post- classic Maya Communities. World Archaeology 31:93-120.

Masson MA. Peraza Lope C 2008. Animal use at the Post-classic Maya center of Mayapán. Quaternary International 191:170-183.

McKillop HI 1985. Prehistoric exploitation of the manatee in the Maya and circum-Caribbean areas. World Archaeology 16:337- 353.

MINADER Regional delegation for West-Cameroon 2014. The state of Cameroon's Biodiversity for food and agriculture. www.fao.org/3/CA3431EN/ca3431. 
Ministère de l'Administration Territoriale et de la Décentralisation (MINATD) 2014. Annuaire statistique. MINATD/DOT.

Pohl M 1976. Ethnozoology of the Maya: An Analysis of Fauna from Five Sites in the Peten, Guatemala. Harvard University, Boston. Retrieved from http://purl.flvc.org/fsu/fd/

Pohl M 1981. Ritual continuity and transformation in Mesoamerica: Reconstructing the ancient Maya cuch ritual. American Antiquity 46:513-529.

Prins HHT. Grootenhuis JG. Dolan TT 2000. Wildlife conservation by sustainable use. Kluwer Academic Pub.

Thermo Fisher Scientific 1997. Assessment of Nucleic Acid Purity. NanoDrop spectrophotometers. Technical bulletin, $2 \mathrm{p}$. 